\title{
Psychological Empowerment, Innovative Work Behavior and Job Satisfaction
}

\author{
Nasir $^{1}$, Halimatussakdiah ${ }^{2}$ and Irma Suryani ${ }^{3}$ \\ ${ }^{1}$ Syiah Kuala University, Indonesia \\ ${ }^{2}$ Syiah Kuala University, Indonesia \\ ${ }^{3}$ Syiah Kuala University, Indonesia, e-mail: Irma Suryani (irmasuryani@unsyiah.ac.id)
}

\begin{abstract}
Psychological empowerment at work contributes to higher individual's performance which eventually facilitates institution to accomplish excellent services and performance. Few studies have examined the specific relationships between these three constructs especially in higher education sector. The aim of this study is to see to what extent psychological empowerment and innovative work behavior affect job satisfaction. From 250 respondents and using SEM AMOS as the analytical tool, the results confirm that psychological empowerment significantly affects innovative work behavior. However, psychological empowerment does not affect job satisfaction unless mediated by innovative work behavior. Meanwhile, innovative work behavior significantly affects job satisfaction.
\end{abstract}

Keywords: Psychological empowerment, higher education sector

\section{Introduction}

Job satisfaction as well as innovative work behavior and psychological empowerment are important roles in implementing efficient and effective work, (Baer \& Frese, 2003; Oldham \& Cummings, 1996; Scott \& Bruce, 1994; Shalley, 1995). Psychological empowerment has been popular and promoted in companies due to its essential impacts in boosting individual's self-efficacy. Being empowered means that an employee perceives more meaningful work, shows more skills at work, has bigger impact, as well as has more choices in completing work tasks. These characteristics are needed in order to achieve more innovative atmosphere at work. Although research in this topic has been widely studied, studies that blend these three variables together to see the relationship among them in individuals in education sector are still very few to date. This study intends to examine the direct or non-direct effect of psychological empowerment and innovative work behavior on the job satisfaction of lecturers at the University of Syiah Kuala.

Job Satisfaction. Locke (1976) stated job satisfaction as a person's relations to his work and how he perceives the work. Fletcher and Williams (2006) believe that job satisfaction is a form of selfevaluation over work condition such as attitude, pay, and security at work. An individual will contemplate his or her work's attributes and feel about them in positive or negative feeling. Positive feelings mean that the work and its characteristics give high value and bring pleasant experience to the worker. In contrast, negative feelings are caused by the unpleasant experiences during work.

Dimensions in job satisfaction according to Smith et al (1969) can be assessed from the extent to which a worker considers the benefits, opportunities for a career development, the friendship among colleagues at work, direction from supervisors, and the work entitled. Numerous studies have used these dimensions by exploring various constructs influencing an employee's satisfaction. One of them is organizational climate factor (Abdel-Razek, 2011). In addition, the key factor of work performance is job satisfaction (Oshagbemi, 2000). Judge et al (2001) and Shmailan (2015) found that there was a relationship between the two constructs. Job satisfaction affects the extent to which an employee shows his level of performance.

Innovative Work Behavior. Janssen (2005) stated that innovative work behavior is one of behaviors shown at work such as through generate, promote, and apply novel ideas. Drawing on West and Farr $(1989,1990)$, innovative behavior refers to an employee's intentional introduction or application of new ideas, products, processes, and procedures to his or her work role, work unit, or organization. 
Innovative work behavior is found in people who actively seek solutions of problems or needs of other people through innovative and novel ideas as well as a person who realizes that trends evolve and needs creative thinking and its application (De Jong \& Den Hartog (2007). Carmeli et al (2006) indicated that in fact teachers' innovative behavior are shown in order to trigger new ideas that could potentially help them in solving problems they find during teaching process, as well as improve their performance, or contribute to solve organization's problems. Ady (2015) stated that the innovative behavior has led farming businessmen to increase their productivities.

Psychological Empowerment. Psychological empowerment is "intrinsic task motivation that manifests itself in four cognitions reflecting an individual's orientation to his or her work roles." (Zhang and Bartol, 2010). Empowerment according to Bowen and Lawler (1992) "as sharing with front-line employees' information about an organization's performance, information about rewards based on the organization's performance, knowledge that enables employees to understand and contribute to organizational performance, and giving employees the power to make decisions that influence organizational direction and performance." Meanwhile, Zemke and Schaaf (1989) identified employee empowerment as turning the "front line" loose and encouraging and rewarding employees to exercise initiative and imagination.

Four psychological empowerment's dimensions according to Thomas and Velthouse (1990) are meaningfulness, competence, impact, and choice. Meaningfulness is the value of the task goal or purpose in relation to the individual's own ideals or standards, and competence is the degree to which a person can perform task activities skillfully. Impact, on the other hand, is the degree to which behavior is seen as making a difference in terms of accomplishing the purpose of the task, while choice is the causal responsibility for a person's actions.

Psychological empowerment and innovative work behavior. Pieterse et al in 2010 conducted a study regarding empowerment at work. In the study they indicated that transformational leadership influences the innovative behavior of workers at work with psychological empowerment mediating the relationship. Psychologically empowered individuals see themselves as competent and able to influence their jobs and work environments in meaningful ways, facilitating proactive behavior, showing initiative, and acting independently (Spreitzer, 1995; Thomas \& Velthouse, 1990).

Competence as one of dimensions in empowerment is reflected through high or low self-efficacy and self-esteem. Higher self-efficacy predicts more creative behavior. Moreover, creativity is also found to be correlated when a teacher has more control over her work which leads to more choices given (Davis \& Wilson, 2010). In addition, Spreitzer (1995), Erturk (2012), and Zhang \& Bartol (2010) stressed that higher self-determination and psychological empowerment boosts innovation and creativity among staffs at work.

Based on literature above, following hypothesis is formulated:

$\mathrm{H}_{1}$ : Psychological empowerment has a significant effect toward innovative work behavior.

Psychological empowerment and job satisfaction. Considerable studies have related four elements of psychological empowerment and job satisfaction. An early study conducted by Thomas and Velthouse revealed that job satisfaction is correlated with psychological empowerment and lower level of meaning at work manifests to low level of satisfaction. Later, Spreitzer et al in 1997 confirmed that psychological empowerment related to work satisfaction, particularly in selfdetermination and competence dimension; whereas impact has no effect. Surprisingly, in 2004 Carless tested psychological climate and job satisfaction with empowerment as mediation, the research revealed that empowerment mediated the correlation between climate and job satisfaction where dimensions of meaning and competence are dominant factors influencing the relationship.

Moreover, staff empowerment in relation with job satisfaction has been widely studied in nursing literature. One of the researches was done by Laschinger et al in 2001 that showed psychological empowerment predicts both job strain and work satisfaction.

Job satisfaction among teachers will be higher when teachers are given more space in decision making process or when they are more involved in the process (Blasé and Blasé 1994; Blasé et al. 1995; 
Shreeve et al, 1987). In addition, Thomas and Tymon (1994) indicated that empowerment creates intrinsic motivation which trigger job satisfaction.

Based on literature above, following hypothesis is formulated:

$\mathrm{H}_{2}$. Psychological empowerment has a significant effect toward job satisfaction.

Innovative work behavior and job satisfaction. Job satisfaction is shown through the feeling of happy toward the job and the fulfilment of needs of psychological such as autonomy, competence, and need for relatedness such as support from the workplace or environment (Deci et al., 2001). When a person completes the work, innovative work behavior is shown along with the competence in executing the tasks. By being able to conduct the task, especially by including some new innovative ideas in it, a person will feel satisfied. A creative individual commonly has competence to face some challenges at work. By fulfilling this need of psychological, the satisfaction would get higher. Previous research found that there is a strong relationship between innovation (Ibrahim, 2015) and job satisfaction (Carmeli, Meitar \& Weisberg, 2006; Tsai, 2014).

Based on literature above, following hypothesis is formulated:

$\mathrm{H}_{3}$. Innovative work behavior has a significant effect toward job satisfaction.

$\mathrm{H}_{4}$. Psychological empowerment has a significant effect toward job satisfaction with innovative work behavior as mediation.

Below is the image of relationship among variables proposed:

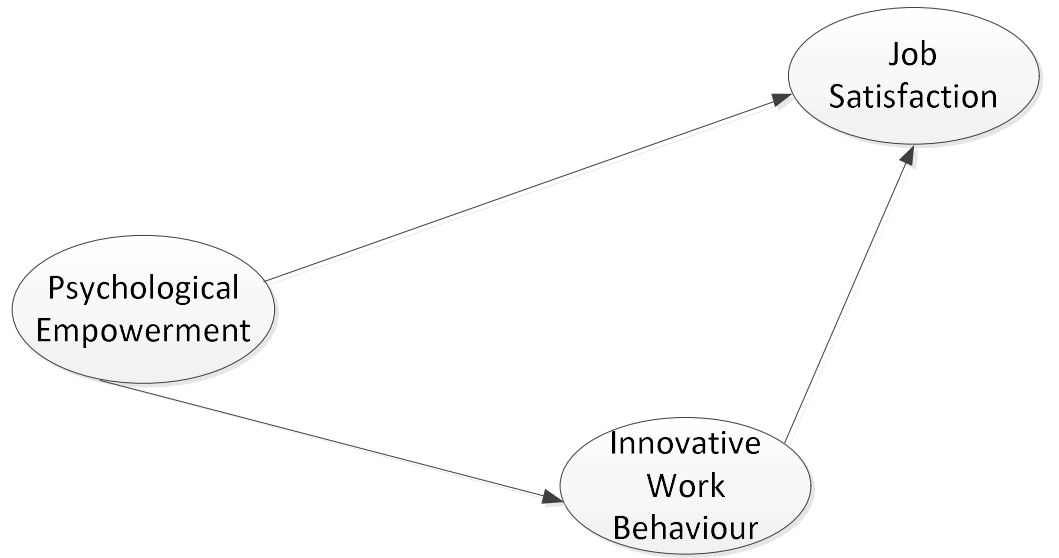

Figure 1. Research Model Nasir et al., 2018

\section{Research Methodology}

This research involves three variables namely psychological empowerment, innovative work behavior, and job satisfaction. This research is a descriptive and quantitative research which was started by mapping the literature relating to the concept of the research. Then, researchers collected some supporting data related to the lecturers as the population of this study by looking at website https://data.unsyiah.ac.id/index.php/dosen. Later, data were analyzed using the Structural Equation Modeling (SEM) method in order to provide a model of lecturers' performance in University of Syiah Kuala. 
Both primary and secondary data were used in this research. Primary data derived from observations, interviews, and survey. Meanwhile, the secondary data derived from searching some related literature review of the previous studies in journals, textbooks, printed and electronic reports. In addition, researchers also did some observation by attending some classes, research process, and community service done by lecturers. From 1441 lecturers in total, the sample using cluster sampling technique was around 300 lecturers from 12 departments. The set of both printed and online questionnaires was given to the lectures. All questions in questionnaires were translated to Indonesian. 5 questions were adopted from Janssen (2000) for innovative work behavior, 5 job satisfactions questions were adopted from Troesch and Bauer (2017), and finally 5 questionnaires were adopted for psychological empowerment.

\section{Result and Discussion}

In accordance with the theoretical framework of the study, the analysis design was used to prove the presence or absence of the influence of psychological empowerment and innovative work behavior on the job satisfaction of teaching staff at Syiah Kuala University.

Structural Equation Modeling (SEM) program was used to analyze the relationships among variables in this study. The application of structural equation modeling follows the following steps (Hair et al., 1998; 2010), namely developing theory-based models, forming path diagrams, converting various paths into equations, selecting input matrix types and model assumptions, identifying models, estimating evaluations model and goodness-of-fit, as well as interpretation and modification of the model.

Respondent Characteristics. Respondents in this study are lecturers at the Syiah Kuala University. The number of questionnaires in this study was 250, but only $229(91.6 \%)$ could be analyzed, 21 $(8.4 \%)$ were incomplete. Characteristics of respondents consisted of age, gender, rank and class, level of education, research and service for community for the last 3 (three) years. Based on age level, 82 (35.8\%) respondents were between 30-40 years, 79 (34.5\%) were between $41-50$ years, 56 (24.5\%) were between 51-60 years, $9(3.9 \%)$ less than 30 years, and $3(1.3 \%) 61$ years and above.

Based on gender, $116(50.7 \%)$ respondents were male and $113(49.3 \%)$ were women. Based on seniority, $45.4 \%$ were in lower level/young lecturers, $28.4 \%$ were in middle level lecturer, $6.9 \%$ were the senior lecturers. Based on education level, 139 (60.7\%) graduates of master's degree and 90 (39.3\%) graduated from Phd.

Measurement Model test. The results of AMOS computation for the measurement model in the first stage have shown the value of loading factors that have met the required standards and the goodnessof-fit index value has met the required cut-off value, evidenced by a good RMSEA index value (0.051), GFI (0.924), AGFI (0.882), CMIN-DF (1351), TLI (0.972) and CFI (0.979). This value is within the range of expected values, so this model is acceptable.

Based on the test results it can be stated that there are three variables that are different from the indicators. Thus, it can be concluded that the Goodness-of-fit Index measurement model is good and further testing can be done, namely testing structural equation modeling.

Structural Equation Model (SEM) test. Model testing in SEM is a two-stage test, namely measurement model test and structural model test (Anderson \& Gerbing, 1988). The results of the first stage of testing show that the model is fit with the existing sample data. Thus, the process of structural model testing can already be done. The results of structural model testing as shown in Image. 2. 


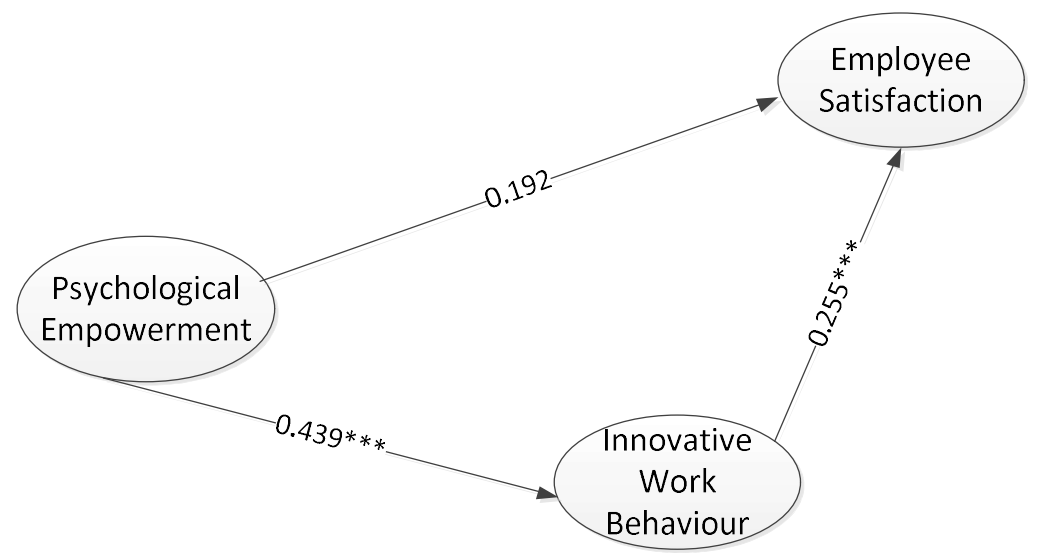

Figure 2. Structural Test Result

Based on the results of structural testing, it is known that the model is fit with the existing data. This is evidenced by the good RMSEA index value (0.048), GFI (0.925), AGFI (0.881), CMIN-DF $(1,313)$, TLI $(0.975)$ and CFI $(0.982)$. This value is within the range of expected values, so this model is acceptable.

Causality Significance Test. The structural model is the relationship between constructs that has a causal relationship, the relationship between these variables can be seen through the figures of the statistical coefficients the results of AMOS calculations as shown in the table below.

Table 1. Results of analysis

\begin{tabular}{|c|l|c|c|l|}
\hline No & \multicolumn{1}{|c|}{ Analysis } & $\begin{array}{c}\text { Direct } \\
\text { effect }\end{array}$ & $\begin{array}{c}\text { Indirect } \\
\text { effect }\end{array}$ & \multicolumn{1}{|c|}{ Result } \\
\hline 1 & $\begin{array}{l}\text { Psychological Empowerment } \rightarrow \\
\text { Innovative Work Behavior }\end{array}$ & $0.439^{* * *}$ & - & Significant \\
\hline 2 & $\begin{array}{l}\text { Psychological Empowerment } \rightarrow \text { Job } \\
\text { Satisfaction }\end{array}$ & 0.192 & - & $\begin{array}{l}\text { Not } \\
\text { significant }\end{array}$ \\
\hline 3 & $\begin{array}{l}\text { Innovative Work Behavior } \rightarrow \text { Job } \\
\text { Satisfaction }\end{array}$ & $0.255^{* * *}$ & - & Significant \\
\hline 4 & $\begin{array}{l}\text { Psychological Empowerment } \rightarrow \\
\text { Innovative Work Behavior } \rightarrow \text { Job } \\
\text { Satisfaction }\end{array}$ & - & $0.112^{* * *}$ & Significant \\
\hline
\end{tabular}

Note: $* * *$ significant at 0.05

Hypotheses Test. The direct effect of psychology empowerment variables on innovative work behavior variables is 0.439 with probability values of 0.001 and a significance level of 0.01 , these results support the first hypothesis (H1). The direct effect of the psychology empowerment variable on the job satisfaction variable is 0.192 with a probability value of 0.112 , this effect is not significant, thus rejecting the second hypothesis $(\mathrm{H} 2)$.

The direct effect of the innovative work behavior variable on the job satisfaction variable is 0.255 with a probability value of 0.005 and a significance level of 0.01 , thus not rejecting the third hypothesis (H3). The indirect effect of the psychology empowerment variable on the job satisfaction variable is 0.112 with a probability value of 0.038 at the 0.05 significance level. This indirect influence is mediated by innovative work behavior variables. The direct influence of psychology empowerment variables on job satisfaction is insignificant, but after mediating innovative work behavior, this influence becomes significant. Thus, the fourth hypothesis (H4) is accepted. 
The results of this study indicate that job satisfaction is influenced by innovative work behavior, the results of this study support the results of previous studies (Ibrahim, 2015). To improve employee job satisfaction, leaders must provide space for innovative work behaviors, including providing opportunities to innovate to staff, providing space to find new methods, techniques, and instruments at work, providing opportunities for staff to create new ideas, introducing systematic innovative ideas in work practices and contribute to the implementation of new ideas (Janssen, 2000).

The results of this study also show that innovative work behavior is influenced by psychological empowerment. Previous research stating that innovative work behavior is influenced by psychological empowerment (Erturk, 2012). To improve innovative work behavior, leaders must provide delegation to people who have a sense of responsibility, disseminate information widely to staff in need, provide space for staff to complete the workload assigned to them according to their abilities and expertise.

\section{Conclusion}

Based on the results of the research and discussion, the authors conclude as follow: psychological empowerment has a significant effect on innovative work behavior. Innovative work behavior has a significant effect on job satisfaction. The effect of psychological empowerment on job satisfaction is directly insignificant but becomes significant after mediation from innovative work behavior. Thus, the role of mediating innovative work behavior becomes important and is the novelty of this research.

\section{References}

Abdel-Razek, W. A. (2011). Factors affecting the effectiveness of the job performance of the specialists working in the youth care at Helwan University. World Journal of Sport Sciences, 4, 116-125.

Ady, M. M. A. (2015). Findings in Interviews on Motivation of Farmers for the Improvement of Paddy Rice Quality and the Implementation of New Methods of Paddy Rice Production in the Chiba Prefecture. 人文社会科学研究 第 31 号. Retrieved from https://core.ac.uk/download/pdf/97064981.pdf

Baer, Markus., \& Frese, Michael. (2003). Innovation is Not Enough: Climates for Initiative and Psychological Safety, Process Innovations, and Firm Performance. Journal of Organizational Behavior, 24, 45 - 68. 10.1002/job.179.

Blase,I., J. Blasé., G. Anderson., \& S. Dungan. (1995). Democratic principals in action: Eight pioineers. Thousand Oaks, CA: Convin Press.

Blase, I., \& I. R. Blase. (1994). Empowering teachers: What successful principals do. Thousand Oaks, CA: Corwin.

Bowen, D. E., \& Lawler, E. E. (1992). The empowerment of service workers: what, why, how, and when. Sloan Management Review, 33, 31-39.

Carless, S.A. (2004). Does Pyschological Empowerment Mediate the Relationship Between Psychological Climate and Job Satisfaction?. Journal of Business and Psychology, 18, 405. https://doi.org/10.1023/B:JOBU.0000028444.77080.c5

Carmeli, A., Meitar, R., \& Weisberg, J. (2006). Self-leadership skills and innovative behavior at work. International Journal of Manpower, 27,1, 75-90.

Davis, J., \& Wilson, S. M. (2000). Principals' efforts to empower teachers: Effects on teacher motivation and job satisfaction and stress. The Clearing House, 73, 349-353.

Deci EL., Ryan RM., Gagne' M., Leone DR., Usunov J., \& Kornazheva BP. (2001). Need satisfaction, motivation, and well-being in the work organizations of a former Eastern Bloc country: a cross-cultural study of self- determination. Pers. Soc. Psychol. Bull. In press.

De Jong, Jeroen., \& Den Hartog, Deanne. (2007). How Leaders Influence Employees' Innovative Behaviour. European Journal of Innovation Management, 10, 41-64. 10.1108/14601060710720546. 
Ertürk, A. (2012). Linking psychological empowerment to innovation capability: Investigating the moderating effect of supervisory trust. International Journal of Business and Social Science, 3, 14.

Fletcher, Clive., \& Williams, Richard. (1996). Performance Management, Job Satisfaction and Organizational Commitment1. British Journal of Management, 7, 169 - 179. 10.1111/j.14678551. 1996.tb00112. x.

Hair, J., Black, W., Babin, Barry., \& Anderson, Rolph. (2009). Multivariate data analysis. London: Prentice Hall.

Janssen, O. (2005), The joint impact of perceived influence and supervisor supportiveness on employee innovative behaviour. Journal of Occupational and Organizational Psychology, 78, 573-579. doi:10.1348/096317905X25823.

Judge, T.A., Thoresen, C.J., Bono, Joyce., \& Patton, G.K. (2001). The job satisfaction-job performance relationship: a qualitative and quantitative review. Psychological Bulletin, 127, 376-407.

Laschinger, H.K.S., Finegan, J., Shamian, J., Wilk, P. (2001), Impact of structural and psychological empowerment on job strain in nursing work settings: expanding Kanter's model. Journal of Nursing Administration, 31, 260-72.

Locke, Edwin. (1976). The Nature and Causes of Job Satisfaction. The handbook of industrial and organizational psychology. 31.

Oldham, G., \& Cummings, A. (1996). Employee Creativity: Personal and Contextual Factors at Work. The Academy of Management Journal, 39, 607-634. Retrieved from http://www.jstor.org/stable/256657.

Oshagbemi, Titus. (2000). Gender differences in the job satisfaction of university teachers. Women in Management Review, 15, 331-343. https://doi.org/10.1108/09649420010378133.

Pieterse, A. N., Van Knippenberg, D., Schippers, M., \& Stam, D. (2010). Transformational and Transactional Leadership and Innovative Behavior: The Moderating Role of Psychological Empowerment. Organization Behavior, 31, 609-623. doi:10.1002/job.650.

Scott, S., \& Bruce, R. (1994). Determinants of Innovative Behavior: A Path Model of Individual Innovation in the Workplace. The Academy of Management Journal, 37, 580-607. Retrieved from http://www.jstor.org/stable/256701.

Shalley, C. E. (1995). Effects of Coaction, Expected Evaluation, And Goal Setting On Creativity and Productivity. Academy of Management Journal, 38, 483-503.

Shipton, H.J., West, M.A., Parkes, C.L., Dawson, J.F., \& Patterson, M.G., (2006). When promoting Positive Feelings Pays: Aggregate Job Satisfaction, Work Environment Features and Innovation in Manufacturing Organizations. European Journal of Work and Organizational Psychology, 15 4, pp. 404-430.

Shmailan, A. S. B. (2015). The Relationship Between Job Satisfaction, Job Performance and Employee Engagement: An Explorative Study. Issues in Business Management and Economics, 4, 1-8. doi: 10.15739/IBME.16.001.

Shreeve, W. C., Norby, I. R., Gpetter, W. G. J., Stueckle, A. F., Midgley, T. K., \& Goetter, P.S. (1987). Job Satisfaction: An Imperative for The Coming Teacher Shortage. (ERIC Document Reproduction Service No. ED 289 818).

Smith, P.C., Kendall, L.M., \& Hulin, C.L. (1969). Measurement of Satisfaction in Work and Retirement. Chicago, IL: Rand McNally.

Spreitzer, G. M. (1995). Psychological Empowerment in the Workplace: Dimensions, Measurement, and Validation. Academy of Management Journal, 38, 1442-1465.

Thomas, K. W., \& Velthouse B. A. (1986). Cognitive elements of empowerment. Paper presented at the meeting of the National Academy of Management, Chicago, 11. 1990. Cognitive elements of empowerment: An "interpretive" model of intrinsic task motivation. Academy of Management Review, 15, 666-81. 
Tymon, W. G., 1r. (1988). An empirical investigation of a cognitive model of empowerment. Doctoral diss., Temple University 1988. Dissertation Abstracts International, 49/08-A (University Microfilms NO.88-18,866).

Thomas, K., \& Tymon, W. (1994). Does Empowerment Always Work? Understanding the Role of Intrinsic Motivation and Personal Interpretation. Journal of Management Systems, 6, 1-13.

Thomas, K. W., \& Velthouse, B. A. (1990). Cognitive elements of empowerment: an interpretive model of intrinsic motivation. Academy of Management Review, 15, 666-681.

Wang, CJ., \& Tsai, CY. (2014) 8: 313. https://doi.org/10.1007/s11628-013-0201-2.

West, M.A., \& Farr, J.L. (1989). Innovation at Work: Psychological Perspectives. Social Behavior, 4, 15-30.

Zemke, R., \& Schaaf, D. (1989). The Service Edge: 101 Companies That Profit from Customer Care. New York, NY: New American Library.

Zhang, X., \& Bartol, K.M. (2010). Linking Empowering Leadership and Employee Creativity: The Influence of Psychological Empowerment, Intrinsic Motivation, and Creative Process Engagement. Academy of Management Journal, 53, 107-128. http://dx.doi.org/10.5465/AMJ.2010.48037118. 